\title{
THE "RULE OF REASON": WORKABLE COMPETITION OR WORKABLE MONOPOLY?
}

\author{
WALTER ADAMS $\dagger$
}

"Vice is a monster of such frightful mien
That to be hated needs but to be seen,
But seen too oft, familiar with her face
We first endure, then pity, then embrace."

Alexander Pope

As part of the currently fashionable and pervasive revisionism, there have been numerous attempts to formulate a new approach to the monopoly problem. Two of these efforts deserve special attention-the report by the Business Advisory Council of the Secretary of Commerce ${ }^{1}$ and the monumental study by Professor $\mathrm{S}$. Chesterfield Oppenheim. ${ }^{2}$ They reach strikingly similar conclusions and offer parallel recommendations. Both find that recent judicial interpretation of the antitrust laws has been shifting, vague, confusing, and uncertain; that a unifying standard for judging antitrust violations is imperative; and that such a standard can be achieved through revitalization of the "Rule of Reason" and acceptance of "Workable Competition." Both studies concur in Professor Oppenheim's assurance that "the broad discretion delegated by Congress in the Rule of Reason and Workable Competition rtle need not be feared as an erosion of antitrust administration and enforcement." 3 'hile this may at first blush appear to be old wine in new bottles, the new approach represents a significant departure in the antitrust field. Its importance lies in the combination of legal and economic pragmatism into an instrument for attacking the traditional philosophy of antitrust. It is the thesis of this article that the new approach is subject to severe limitations, if not fatal defects; that the interpretation of the Sherman Act is far less uncertain than its critics imply; that a "Rule of Reason," as these critics use the phrase, would mean judicial emasculation of Section 1 of the Act ; and

iAssociate Professor of Economics, Michigan State College. The author is indebted to Professor James W. Payne, Jr., of the University of Richmond Law School for help. ful criticisms and suggestions.

1. Business Advisory Council, Effective Competition (1952) (hereinafter cited as Business Advisory Council).

2. Oppenheim, Federal Antitrust Legislation: Guideposts to a Revised National Antitrust Policy, 50 Mich. L. Rev. 1139 (1952) (hereinafter cited as Oppenhems).

3. OPPENHEIM 1196.

4. "Sec. 1. Every contract, combination in the form of trust or otherwise, or conspiracy, in restraint of trade or commerce among the several States or with foreign nations, is hereby declared to be illegal." 26 Stat. 209 (1890), 15 U.S.C. $\$ 1$ (1946). 
finally, that acceptance of what they mean by "Workable Competition" would be tantamount to a toleration of monopoly under Section 2.5

Under Section 1 of the Act, the courts have confronted the problem of determining whether or not a given business arrangement involved a restriction of competition which was to be conclusively presumed "unreasonable." Business arrangements which fall into the categories of price fixing, ${ }^{6}$ market sharing, ${ }^{7}$ or boycotts growing out of joint action among competitors ${ }^{8}$ are subject to this conclusive presumption which makes them illegal per se. Some commentators have chosen to regard this per se doctrine as part of, and subsumed under, the rule of reason. They have argued that "per se" does not eliminate the necessity of exercising reasonableness in determining whether or not a given arrangement fits into a forbidden category. ${ }^{9}$ Other commentators, however, feel that the per se doctrine and the rule of reason are incompatible; that there is a sharp dichotomy dividing the two; that the per se doctrine forecloses an examination of the reasonableness (economic desir-

5. "Sec. 2. Every person who shall monopolize, or attempt to monopolize, or combine or conspire with any other person or persons to monopolize any part of the trade or commerce among the several States, or with foreign nations, shall be deemed guilty. . . ." 26 STAT. 209 (1S90), 15 U.S.C. \$2 (1946).

Although all commentators reject the standard of "pure" or "perfect" competition, there is disagreement as to the nature of the substitute standard-"workable compatition." Some view it as giving "equal emphasis on market structure and market behavior." Rostow \& Sachs, Entry into the Oil Refining Business: Tertical Integration Ke-coramined, 61 YALE L.J. 856,862 (1952). Others emphasize the performance of the defendants in their industry. Mason, The Current Status of the Monopoly Problen in the Urited States, 62 HARv. L. Rev. 1265, 1281-2 (1949). Oppenheim and the Business Advisory Council adopt the latter view and emphasize the market performance criterion. Althtsugh the author agrees with Professor Rostow, we shall, for purposes of this article, be referring to the market performance viewpoint when discussing the "workable competition" advowted by Professor Oppenheim and the Business Advisory Council.

6. See United States v. Socony-Vacuum Oil Co., 310 U.S. 150 (1940); United States v. Trenton Potteries Co., 273 U.S. 392 (1927); Addyston Pipe \& Steel Co. v. United States, 175 U.S. 211 (1899); United States v. Trans-Missouri Freight Ass'n, 166 U.S. 290 (1897).

7. United States v. Timken Roller Bearing Co., 341 U.S. 593 (1951); United States v. National Lead Co., 332 U.S. 319 (1947) ; United States v. Imperial Chemicals Industries, Ltd., 105 F. Supp. 215 (S.D.N.Y. 1952).

8. Fashion Originators' Guild v. FTC, 312 U.S. 457 (1941).

9. As Professor Handler points out with regard to the Trade Associalion Cases, the ultimate question "has been whether it can fairly be said that implicit in the plan is an agreement or understanding with regard to the price or production policy to be pursued by the members of the combination, or whether there is an agreement or understanding otherwise restrictive of competition." HANDLER, A Study of tue Constructro:: And E::FoRCENent of THE ANTI-TRUst Laws 19 (TNEC MLonograph 38, 1941). The courts have not "given much weight to proof that the motives of the members of the combination have been beneficent, that there has been no sinister purpose or abuse of economic power, or that the objectives of the plan may have been economically justifiable." Ibid. Thus discretion was exercised in determining whether or not a trade association's activity con- 
ability) of a given business arrangement, whereas a genuine rule of reason should not. Since both Professor Oppenheim and the Business Advisory Council take the latter view of a rule of reason under Section 1, we shall, for purposes of this article, accept their definition.

\section{UNCERTAINTY}

The Business Advisory Council complains that: "The interpretation and administration of the Antitrust Laws are so lacking in consistent clear standards related to practical performance that no businessman can tell whether or not he is conforming with or violating the spirit and intent of the various statutes. The businessman's lawyer cannot give reliable guidance."10 In endorsing this view, Professor Oppenheim states that "growing uncertainty as to just where the federal government is headed in its administration and enforcement of this mass of antitrust laws is casting the shadow of an enormous question mark over many important business decisions which are made today."11 It is this charge of uncertainty which is then made the basis of demands for legislative revisions. The extent to which the charge is justified depends on the extent to which the law is, in fact, uncertain.

With respect to price fixing agreements, judicial interpretation of Section 1 has remained surprisingly constant over the years. In the Addyston Pipc \& Steel case, ${ }^{12}$ Judge Taft refused to examine the reasonableness of the agreement; he refused to "set sail on a sea of doubt" and to assume the power of saying "how much restraint of competition is in the public interest, and how much is not." 13 He wisely observed that "the manifest danger in the administration of justice according to so shifting, vague, and indeterminate a standard would seem to be a strong reason against adopting it."14 And, in Standard Oil Co. v. United States, ${ }^{15}$ the Supreme Court declared that agreements, if "clearly restraints of trade within the purview of the statute, . . . could not be taken out of that category by indulging in general reasoning as to the expediency or non-expediency of having made the contracts or the wisdom or want of wisdom of the statute which prohibited their being made."10 Here was the nucleus of the per se doctrine to which the Business Advisory Council and Professor Oppenheim take unqualified exception.

stituted a restraint of trade; but once such a restraint-more than de minimis-was found to exist, any potential justification thereof on the grounds of reasonableness was foreclosed. Adoption of the per se doctrine according to Handler, "does not eliminate the element of discretion. It does, however, establish the metes and bounds of such discretion and preciudes the voyage upon [a] chartless sea of doubt." Id. at 9.

10. Business Advisory Council 4.

11. OPPENHEIM 1140-1.

12. United States v. Addyston Pipe \& Steel Co., 85 Fed. 271 (6th Cir. 1898).

13. Id. at 284.

14. Ibid.

15. 221 U.S. 1 (1911).

16. Id. at 65 . 
This per se doctrine was further crystallized in the Trenton Potteries case. ${ }^{17}$ There Mr. Justice Stone held that every price fixing agreement, if effective, eliminates one form of competition. He rejected the defense that fixed prices, if reasonable, cause no injury to the public interest. The ratio decilendi was unmistakable: the reasonable price of today may become the unreasonable and arbitrary price of tomorrow. Under Oppenheim's rule of reason, and in the absence of competition, enforcement agencies would be compelled to conduct continuous and minute inquiry into the reasonableness of a particular price; they would have to ascertain from day to day whether an initially reasonable price had, through the normal change of economic conditions, become unreasonable. Hence, Justice Stone concluded, "Agreements which create such potential power may well be held to be in themselves unreasonable or unlawful restraints. . . ."18 He hesitated "to adopt a construction making the difference between legal and illegal conduct in this field of business relations depend upon so uncertain a test as whether prices are reasonable-a determination which can be satisfactorily made only after a complete survey of our economic organization and a choice between rival philosophies."19

After a deviation in the Appalachian Coals case, 0 the per se doctrine was again applied in the Socony-Vacuum case.21 There Justice Douglas affirmed the Trenton Potteries doctrine, and in numerous dicta condemned both abortive and successful, direct and indirect means of tampering with the price structure through joint action among competitors. Price fixing agreements were declared to be unlawful under Section 1 of the Sherman Act regardless of the amount of interstate or foreign commerce involved." "Whatever may have been the status of price-fixing agreements at common law ... the Sherman Act has a broader application to them than the common law prohibitions or sanctions. . . Whatever economic justification particular price-fixing agreements may be thought to have, the law does not permit an inquiry into

17. United States v. Trenton Potteries Co., 273 U.S. 392 (1927).

18. Id. at 397 .

19. Id. at 398 .

20. Appalachian Coals, Inc. v. United States, 288 U.S. 344 (1933). Despite MIr. Justice Douglas' heroic, but unpersuasive, attempt to distinguish rather than overrule the Appalaclian case in United States v. Socony-Vacuum Oil Co., 310 U.S. 150, 214 (1940), few would regard Appalachian as a controlling precedent today. By way of explaining the Court's deviation from the per se doctrine in this case, it may be relevant to note that the program in question "concerned itself with efforts to mitigate the hardships of producers in a hopelessly disorganized and depressed industry during a pariod of general depression and ... that it was submitted to the court before it was put in operation." Hander, A Study of the Construction ano Exfoscenent of the Antitaust Liws 33 (TNEC Monograph 38, 1941). It appears doubtiul that the identical facts would have led the Court to the same decision had the case come up at the time of Socony-lyacumm, seven years later.

21. United States v. Socony-Vacuum Oil Co., 310 U.S. 150 (1940).

22. Id. at 224 n.59. 
their reasonableness. They are all banned because of their actual or potential threat to the central nervous system of the economy."23

Subsequently the per se doctrine was apparently extended to boycotts growing out of joint action by competitors, ${ }^{24}$ and to price fixing agreements and market sharing arrangements in foreign commerce. ${ }^{25}$ In view of this almost monolithic evolution of the case law under Section 1, it is difficult, if not impossible, to ascertain the respects in which the law is unclear or uncertain. In fact, it could readily be argued that the trouble with Section 1 is not that it is unclear, but that it has become painfully clear, and that the hope of prospective price fixers is not to clarify the trend, but to reverse it. ${ }^{20}$

Experience justifies a less drastic view of the clamor for clarifying Section 2 of the Act. Here there has been considerable judicial vacillation. In the earlier cases under Section 2, the courts tended to follow the rule that "size does not determine guilt; that there must be some 'exclusion' of competitors; that the growth must be something else than 'natural' or 'normal'; that there must be a 'wrongful intent,' or some other specific intent; or that some 'unduly' coercive means must be used."27 Since World War II, however, the courts have tended to emphasize the significance of market power, and to infer a general intent to monopolize from a course of conduct directed toward

23. Ibid.

24. Fashion Originators' Guild v. FTC, 312 U.S. 457 (1941).

25. See cases cited note 7 supra.

26. This is a paraphrase of Professor Latham's comment on the campaign to "clarify" the legality of basing point pricing. See Latham, The Politics of Basing Point Legislation, 15 LAw \& Contenr. Prob. 272, 273 (1950).

27. United States v. Aluminum Co. of America, 148 F.2d 416, 429 (2d Cir. 1945). This test was applied in Standard Oil Co. v. United States, 221 U.S. 1 (1911), and in United States v. American Tobacco Co., 221 U.S. 106 (1911); it was affirmed in United States v. U. S. Steel Corp., 251 U.S. 417, 451 (1920); it was ignored in United States v. Reading Co., 253 U.S. $26(1920)$; it was reaffirmed in United States v. International Harvester Co., 274 U.S. 693, 708 (1927); and it was diluted in United States v. Swift \& Co., 286 U.S. 106, 116 (1932) ("Mere size . . . is not an offense against the Sherman Act unless magnified to the point at which it amounts to a monopoly. . . , but size carries with it an opportunity for abuse that is not to be ignored when the opportunity is proved to have been utilized in the past.").

The Reading case was obviously inconsistent with the then prevailing monopoly test. As Professor Handler points out, "No one can read the Court's opinion [in Reading] without feeling that what is being forbidden is the combination of giant companies doing a substantial part of the business in their fields. It matters not that the combination in no way approaches monopoly control, that it possesses no power to fix prices, or acting alone, to exclude competitors, that the effects of the combination and intentions of the defendants are of the best, that the power so obtained is not abused. The important clement is the elimination of competition between the combining units." Handler, Indisstrial Mergers and the Anti-Trust Laws, 32 CoL. L. Rev. 179, 230 (1932). According to Handler, the Court reached diametrically opposite conclusions in the Reading and U. S. Stecl cases, although the cases are undistinguishable on the facts. He points out that the majority opinion in Reading bears an unmistakable resemblance to the minority opinion in U. S. Steel. Id. at 233. 
the achievement, retention, or extension of monopoly power..$^{\text {s }}$ A monopolist was presumed to have engaged in monopolization unless he could show that monopoly "was thrust upon" him."2 With increasing clarity there has emerged the view that Section 2 does not condone good trusts and condemn bad trusts, but forbids all trusts. ${ }^{30}$ Under the "new" Sherman Act, standard applied in Section 2 cases is not whether prices have actually been raised or competitors actually excluded, but whether power exists, coupled with an intent and purpose, to raise prices and exclude competitors whenever it is desired to do so. ${ }^{32}$ It is this test-the so-called market structure testwhich is coming into sharper focus and which is now the object of growing criticism. While the test may ultimately be rejected as economically unfeasible or undesirable, it cannot be attacked as legally unclear.

Yet the alleged unclarity and vagueness of the case law is offered as justification for the persistent effort to upset the per se doctrine under Section 1, and the market structure test under Section 2 of the Sherman Act. The remedy suggested both by Professor Oppenheim and the Business Advisory Council is the application of the rule of reason to both sections. As the Business Advisory Council put it: "The old Rule of Reason, if applied, would cure part of the problem, if revived, because it is flexible-but it is also highly indefinite. Most businessmen and lawyers, even so, prefer the flexibility of a Rule of Reason, even with its indefiniteness." 33 In a way, this argument lets the cat out of the bag. Its inconsistency with the demands for greater clarity and certainty is so obvious, that it is best treated sub silcritio.

However, there is another cure for uncertainty which does require comment. The Business Advisory Council suggests that provision be made for advisory opinions ("authoritative rulings") on activities which may be variously construed under diverse interpretations of the antitrust laws. ${ }^{3 t}$ The businessman, it is said, is quite willing to comply with the law if he can find out what to comply with. Hence the Council advocates authoritative rulings as well as special legislation to prevent retroactive impact from any reversal of position by the Government. ${ }^{35}$ This procedural change, while it appears innocent and plausible, is both dangerous and unnecessary. Louis D. Brandeis emphasized this rather pointedly when he counseled the newly created Federal Trade Commission not to grant advisory opinions. He argued that it would

28. See, e.g., American Tobacco Co. v. United States, $32 S$ U.S. 781 (1946); United States v. Aluminum Ca. of America, 148 F.2d 416 (2d Cir. 1945).

29. Id. at 429 .

30. Id. at 427 .

31. Rostow, The New Sherman Act: A Positive Instrument of Progress, 14 U. of CEI. L. REv, 567 (1047) ; Rostow, Monopoly Under the Sicrnan Aet: Foncer or Purposc:" 43 ILL. L. REv. 745 (1949).

32. American Tobacco Co. v. United States, 328 U.S. 781, 809,811 (1946).

33. Business Auvisony Counctr 5.

34. Id. at 19.

35. Ibid. 
be impossible for the FTC to determine in advance whether or not the contemplated behavior would result in an improper restraint of trade, and that such a determination would necessitate knowledge of the effect of the contemplated behavior on competitors who would not be available at the advisory hearing. ${ }^{36}$

On the basis of the available evidence, it may not be inappropriate to suggest that interpretation of the Sherman Act is less vague, unclear, and confusing than its critics imply; that if, arguendo, the law's enforcement were indeed vague and shifting, the rule of reason is hardly the appropriate remedy; and finally, that the advisory opinion suffers from defects which may vitiate its utility.

\section{Restraint of Trade}

With respect to Section 1 violations, Professor Oppenheim objects to the per se doctrine because it selects a particular fact, e.g., price fixing, as establishing an irrebuttable presumption of antitrust violation without permitting the respondent to introduce evidence by way of legal or economic justification for the alleged restraint. Under the Oppenheim proposal, by contrast, the Government would still have the burden of proving a contract, combination, or conspiracy in restraint of trade, but such showing would be no more than a prima facie presumption of unlawful conduct. The respondent would then be allowed to present rebuttal evidence to show economic and legal justifications in "harmony with an overriding public interest." 37 As Professor" Oppenheim puts it: "Throughout the whole course of the proceeding, then, the respondent would have a full opportunity to present all the relevant facts

36. Testimony of Louis D. Brandeis, FTC Records 2-9 (1915). "Now, I do not believe, on the other hand, that the difficulty for the businessman is nearly as great as he imagines it to be. I have been at times counsel for a few trusts. The president of one of the largest of them, when we were discussing the law some four or five years ago, and he was full of his attacks against the Sherman Law, said to me, 'Now, you have been speaking in favor of this Sherman Law, and I have been going around and trying to find out what I can do, and I can't get any advice as to what I can do.' And he said, in a rather pleasant enough way, but in certain ways rather sneering, 'Perhaps you can advise me.' I said, 'I can advise you perfectly, but it is a question of what advice I can give you. If you ask me how near you can walk to the edge of a precipice without going over, I can't tell you, for you may walk on the edge, and all of a sudden you may step on a smooth stone, or strike against a little bit of root sticking out, and you may go over that precipice. But if you ask me, how near you can go to the precipice and still be safe, I can tell you, and I can guarantee that whatever mishap comes to you, you will not fall over that precipice. You have taken my advice, and other lawyers' advice about any number of things; and when we give you advice, you act on that advice; and you have given up many a good trade on questions that have had nothing to do with the Sherman Law, at all, because you were not willing to take the risk.' . . . I said, 'You must not expect from the Sherman Law any more than you do from any other law you are dealing with. You must not expect that you can go to the verge of that law without running any risks." Id. at 12.

37. Oppenhem 1157-8. 
he can muster to justify, as an affirmative defense, the merits of his course of conduct. He would, in short, have a full day in court with the knowledge that the trier of fact would give due weight to his side of the controversy. This prima facie case approach appears far more in harmony with due process of law than the present reliance upon per se violation rules in proceedings involving restrictive agreements among competitors." 33 To prevent misuse of his rule of reason as a cloak for subterfuge and evasion of antitrust prohibitions, Professor Oppenheim would place "upon the defendant the burden of proving by clear and convincing evidence the legal justifications set up in his affirmative defense." 39 Thus, while the Government's case would be judged by the preponderant weight of the evidence, the defendant would have to meet the more exacting burden of clear and convincing evidence. With this safeguard, Professor Oppenheim feels that there is little cause to fear an erosion of effective antitrust enforcement.

It is not unfair to say that this approach would replace our traditional reliance on competition as a regulator of economic affairs. Under the new standard, price fixing might be deemed lawful if the prices fixed were reasonable, i.e., did not injure the public interest. The crucial test would be performance; "good" social ends would justify hitherto anti-social means. Or, to put it in the classic parlance of pragmatic realism: as long as the trains are on time, the method of determining schedules is of secondary importance.

It is significant that nowhere does Professor Oppenheim spell out the types of defenses to be admitted by way of rebutting a prima facie presumption of unlawful conduct. Yet, judging by the justifications offered in previous price fixing cases, we have some notion of what the leading defenses are likely to be. In the past, the affirmative defenses included the contention that (1) the industry is peculiarly vulnerable to ruinous competition; (2) the prices fixed are reasonable; (3) depressed conditions in the industry make a restraint on price competition imperative; and (4) the price fixing arrangement is innocuous since it lacks the power to set prices. An examination of each of these defenses may throw some light on the efficacy of the "new approach."

\section{Ruinous Competition}

This defense contends that unrestrained price competition, while generally desirable, is unworkable in the industry in question. Thus, in the TransMissouri case ${ }^{20}$ defendants claimed that "competition while, perhaps, right and proper in other business, simply leads in railroad business to financial ruin and insolvency." 11 In the railroad industry, with its heavy capital investments and decreasing costs per unit, each road must attract additional freight in order to increase revenues. Since other roads are similarly moti-

38. Id. at 1159 .

39. Id. at 1160 .

40. United States v. Trans-MIissouri Freight Ass'n, 166 U.S. 290 (1897).

41. Id. at 330 . 
vated, any price cut will meet with inevitable retaliation-to the detriment of all. "The only refuge, it is said, from this wretched end lies in the power of competing roads agreeing among themselves to keep up prices for transportation to such sums as shall be reasonable in themselves, so that companies may be allowed to save themselves from themselves, and to agree not to attack each other, but to keep up reasonable and living rates for the services performed." 42

Similar claims have been made for other industries. A former trustee of the Cement Institute, for example, in defending the collusive basing point system, once wrote that cement was an industry "above all others that cannot stand free competition, that must systematically restrain competition or be ruined." 43 These examples can be multiplied. All raise the central issue whether exemptions from the antitrust laws should lie in the discretion of the courts, or in the legislative domain of Congress. Certainly, past experience indicates that Congress has granted exemptions without reluctance wherever it thought that a particular situation or the conditions of a particular industry justified such action. ${ }^{44}$ It would seem that in a democracy it is for the elected representatives of the people and not for private groups (subject to judicial veto) to decide whether or not a particular industry is capable of withstanding the rigors of competitive rivalry.

\section{Reasonable Prices}

In every price fixing case, there is inevitably offered the defense that the prices fixed are reasonable. ${ }^{45}$ This raises the fundamental and difficult problem of selecting a proper standard of reasonableness, i.e., a standard suitable for judicial application. ${ }^{46}$ Assuming that a proper standard for judging the

42. Id. at 331 .

43. Quoted in FTC v. Cement Institute, 333 U.S. 683, 706 (1948).

44. Congress has expressly exempted certain specific activities from the Sherman Act. See, e.g., $\S 6$ of the Clayton Act, 38 Stat. 731 (1914), 15 U.S.C. $\$ 17$ (1946) (labor organizations); the Webb-Pomerene Act, 40 STAт. 517 (1918), 15 U.S.C. $\$ 62$ (1946) (foreign trade associations); the Capper-Volstead Act, 42 Stat. 388 (1922), 7 U.S.C. $\$ 291$ (1946) (farm cooperatives); the National Industrial Recovery Act, 48 STat. 198 (1933) (codes of fair competition); the Miller-Tydings Act, 50 St八т. 693 (1937), 15 U.S.C. $\S 1$ (1946) (resale price maintenance); the McCarran-Ferguson Act, 59 STAT. 34 (1945), as amended, 61 STAт. 448 (1947), 15 U.S.C. $\$ 1013$ (Supp. 1952) (insurance companies); the Reed-Bulwinkle Act, 62 Stat. 473 (1948), 49 U.S.C. § 5b (Supp. 1952) (railroad rate agreements).

45. See cases cited note 6 supra.

46. The difficulty of finding such a standard in a case involving railroad rates was described by Mr. Justice Peckham:

"Must the rate be so high as to enable the return for the whole business done to amount to a sum sufficient to afford the shareholder a fair and reasonable profit upon his investment? If so, what is a fair and reasonable profit? That depends sometimes upon the risk incurred, and the rate itself differs in different localities: which is the one to which 
reasonableness of prices can be found, it is at best doubtful whether the courts can provide that detailed and continuous supervision over prices which, in the absence of competition, would be imperative. 27 Moreover, it is questionable whether a court should, in effect, be converted into an administrative agency guarding the public against potential exploitation.

The basic policy question is this: shall the businessman be permitted to forsake competition and engage in price fixing and other trade restraints while simultaneously avoiding effective regulation in the public interest? Can the public be expected to rely on industry self-government, ${ }^{48}$ enlightened stewardship, or benevolent economic despotism as desirable alternatives to a free market? Competition is only one technique of social control; one method for limiting the power of individual firms over the economy. If competition is to be abandoned, an adequate safeguard must be put in its place. The price fixer's fear of potential rebuke by the courts does not appear to be such a safeguard.

\section{Depressed Condition of the Industry}

This defense was most forcefully and persuasively presented in the Appalachian Coals case of 1933.19 Given the depressed condition of the coal industry, it was argued that a joint selling agency covering 73 percent of the producers in the Appalachian field was a reasonable restraint of trade. There was little question about the extent of the industry's distress. Coal was a sick industry which, under the infiuence of World War I expansion, had built up

reference is to be made as the standard? Or is the reasonableness of the profit to be limited to a fair return upon the capital that would have been sufficient to build and equip the road, if honestly expended? Or is still another standard to be created, and the reasonableness of the charges tried by the cost of the carriage of the article and a reasonable profit allowed on that? And in such case would contribution to a sinking fund to malse repairs upon the roadbed and renewal of cars, etc., be assumed as a proper item? Or is the reasonableness of the charge to be tested by reference to the charges for the transportation of the same kind of property made by other roads similarly situated? If the latter, a combination among such roads as to rates would, of course, furnish no means of answering the question." United States v. Trans-Missouri Freight Ass'n, 166 U.S. 290, $331-2$ (1897).

47. On the inability of the courts to evaluate complex economic data, see Mr. Justice Frankfurter's opinion in Standard Oil Co. v. United States, 337 U.S. 293, 310 n.13 (1949).

48. In describing one American experiment with industry self-government, Profescor Kreps observed: "[T]he point must be made emphatic that the NRA was a device conceived by business, put into effect by business, administered by businessmen, and finally, in the Schechter decision of May, 1935, demolished by the Supreme Court on the instance of businessmen." Kreps, Business and Governarent under the Natronal IivdustamL. RECOVERY ACT 18-19 (1936).

49. Appalachian Coals, Inc. v. United States, $2 S S$ U.S. 344 (1933). For a discussion of the public policy alternatives in the coal industry, see Rostow, Bitusminous Coal asd the Public Interest, 50 YaLe L.J. 543 (1941) ; Hamilton, Coal and the Ecossony-A DCmzurrer, 50 Yale L.J. 595 (1941) ; Miller, The Pricing of Bituminous Coal: Sone Intermational Comparisons, 1 Public Policy 144 (1940). 
a capacity exceeding $700,000,000$ tons to meet an annual demand of less than $500,000,000$ tons. Under the impact of the depression of the early 1930's, the bottom had dropped out of the coal market, thus aggravating the long-run decline of coal relative to oil, natural gas, and other fuels. That the problem was further compounded by the increased efficiency of coal in inclustrial uses and by the existence of concentrated power on the buying side of the market was readily conceded. ${ }^{50}$ The question nevertheless remained whether or not the deplorable condition of the industry made the restraint on price competition a reasonable restraint.

The coal industry in 1933 was, of course, a classic milieu for the "depressed industry" argument. ${ }^{.1}$ Yet it is debatable whether, even in this case, the restraint could be justified by sound economic principles. To the extent that coal's afflictions were attributable to the business cycle, the pricing arrangement in question was hardly a suitable remedy. Depressions can be attacked most effectively with countercyclical monetary and fiscal weapons which strike at the root of the difficulty; they cannot be cured by price fixing schemes. ${ }^{62}$ Moreover, overexpansion of capacity cannot be undone even by collusive devices. European cartels, for example, have repeatedly tried to eliminate warborn over-capacity only to find that their artificial restraints tencled to perpetuate such capacity, and intensify competition from non-members and stbstitute products. ${ }^{53}$ Furthermore, the effort to maintain or raise prices artificially is not likely to arrest the long-run decline of one industry relative to competing industries. To the extent that such price manipulations are successful, they tend to accelerate, not arrest, the decline of a depressed industry. Finally, concentration of power on the buying side of the market does

50. In appraising the evidence in the case, the district court found that defendants' plan was "an attempt to organize the coal industry and to relieve the deplorable conditions resulting from overexpansion, destructive competition, wasteful trade practices, and the inroads of competing industries." 1 F. Supp. 339, 341 (W.D. Va. 1932). The district court, however, rejected this justification of the pricing arrangement, and held same to be a violation of Section 1 .

51. The "depressed industry" argument was also attempted in the Socony-Vacilum! case, where defendants urged the necessity of removing "distress" gasoline from the market in order to save the industry from itself. Defendants argued "that they hat affected prices only in the sense that the removal of the competitive evil of distress gasoline by the buying programs had permitted prices to rise to a normal competitive level; that their activities promoted rather than impaired fair competitive opportunities; and therefore that their activities had not unduly or unreasonably restrained trade." 310 U.S. $150,211-12$ (1940).

52. See Boulding, In Defense of Monopoly, 59 Q.J. EcoN. 524 (1945).

53. See Stocking \& Watkins, Cartels In Action c. 3 (1950). Excess capacity, resulting from over-expansion, does not disappear through cartelization. If the cartel allocates the limited demand to its membership through output quotas, or if the cartel attempts to maintain artificial prices (thus curtailing consumption), existing facilitics will not be fully used. This unused capacity represents a cost for which someone-in this case, the consumer-has to pay. Here, as in other areas of economic life, "there is no such thing as a free lunch." 
not justify the promotion of countervailing power on the selling side. An alternative solution, equally logical and more consistent with the competitive philosophy, would be to dispel the source of original market power. In short, the depressed condition of an industry certainly may call for some remedial action; but it is questionable whether unsupervised private action, involving significant departures from competition, constitutes the most fruitful and least dangerous method of attack. 54

\section{Lack of Market Power}

In the Appalachian Coals case defendants argued that only 73 percent of the field's production was covered by the agreement; that Appalachian coal had to compete with that of other regions; that entry into the industry (potential competition) was unfettered; and that defendants' concerted action might incidentally "affect" market price, but could not set it."5i Similarly, in the Socony-Vacuum case, defendants urged that their purchase program for "distress" gasoline had no "effect on the competitive market price beyond that flowing from the removal of a competitive evil; and that if [they] had tried to do more than free competition from the effect of distress gasoline and to set an arbitrary non-competitive price through their purchases, they ayould have been without power to do so."

Assuming these contentions to be valid, it would still be true that attempts to raise, lower, or stabilize prices through joint action of competitors involve a direct interference and tampering with the free play of market forces. Even though a particular price fixing agreement may fall short of power to control or dominate a given market, it still has an influence on market price and may be of considerable value to the conspirators; else they would not, as rational businessmen, adhere to it. Moreover, even a monopolist lacks power -in any absolute sense-to control market price, because he is limited by the competition of substitute products and the fear of potential competition. ${ }^{57}$ Finally, it is to be noted that price fixing is distinct from monopolizing, and that the Sherman Act condemns the former as well as the latter. "The exist-

54. A contrary opinion was expressed by Chief Justice Hughes in the Apralachion: Coals case: "Voluntary action to rescue and preserve [fair competitive] opportunitics, and thus to aid in relieving a depressed industry and in reviving commerce by plaeing competition on a sounder basis, may be more efficacious than an attempt to provide remedies through legal processes." 28S U.S. 344, 374 (1933).

55. "The contention is, and the court below found, that while deiendants could not fix market prices, the concerted actions would 'affect' them, that is, that it would lasic a tendency to stabilize market prices and to raise them to a higher lewel thos would olherwise obtain." 288 U.S. 344, 373 (1933) (emphasis added). The Supreme Court then went on to justify this effect on prices by holding that no "effect will be produced which in the circumstances of this industry aill be detrinumlal to fair competition." Ibid. (emphasis added).

56. 310 U.S. 150,226 n.59 (1940) (emphasis added).

57. See pages $362-4$ infra. 
ence or exertion of power to accomplish the desired objective . . . becomes important only in cases where the offense charged is the actual monopolizing of any part of the trade or commerce in violation of $\S 2$ of the Act. . . An intent and a power to produce the result which the law condemns are then necessary. . . . But the crime under $\S 1$ is legally distinct from that under $\S 2$... Only a confusion between the nature of the offenses under those two sections ... . would lead to the conclusion that power to fix prices was necessary for proof of a price-fixing conspiracy under $\$ 1 .{ }^{\prime 8} 8$ In short, the lack of monopoly power is hardly an adequate defense to a charge of price fixing.

Focusing on the abuses arising from trade restraints, rather than on the restraints themselves, would permit the wholesale cartelization of American industry, provided only that cartel power remained unabused. A comparison of the Oppenheim proposal with the German cartel law of $1923^{60}$ is enlightening. That law provided that if a contract or resolution covering production or marketing policy, or prescribing conditions of trading or methods of fixing prices, should endanger the national economy or the public interest, the Reich Minister of Economic Affairs could "apply to the Cartel Court for a

58. United States v. Socony-Vacuum Oil Co., 310 U.S. 150, 226 n.59 (1940).

59. For a complete text of "Ordinance against the Misuse of Economic Power, Promulgated 2nd November, 1923," see Liefmann, Cartels, Concerns and Trusts 351 et seq. (1932). In fairness to Oppenheim it must be said that he regards cartel-like agreements among competitors as alien to his personal philosophy. Oppenhcim states that, in making his proposal, he has no intention "to give aid to any mechanisms fostering erosion of the basic concept of Workable Competition. ... The writer's plea for a fullscale application of the Rule of Reason in the types of situations here under discussion is not to be taken as an invitation to return to the roseate hues of industrial self-regulation through joint agreements among trade association members or other groups of competitors as advocated in the 1920's and as they flourished in the NRA Codes of Fair Competition during the brief life of the National Industrial Recovery Act." OpPEN neIM 1160.

For an incisive comment on the rule of reason approach in the British Monopolies and Restrictive Practices Act (1948), see Rostow, Britain and Monopolics: An Amcrican Vieze, Manchester Guardian, Feb. 16, 1953, p. 4, cols. 6-7, et seq. In contrasting the British law with the traditional American antitrust philosophy, Rostow observes: "Both the British and the American legislation agree that economic situations in which competition is restricted, either by reason of the relative size of business units within a given market or because of collusive arrangements among a number of relatively smaller firms, present a problem in the public interest. Both Congress and Parliament recognize that such power in a market may be abused, to the detriment of the economy. The American approach is to attack the existence of the power, on the ground that no court or administrative body can maintain a constant review of all sectors of the economy, in order to ascertain whether economic power which is being beneficently used today will also be beneficently used tomorrow. ... The new British law appears to accept the oppositc premise-that there can be 'good' as well as 'bad' monopolies, and that the public interest will be served by holding monopolies to appropriate standards of behavior with regard to the level of their profits, restrictions on the entry of new firms, exclusive dealcrships, discount practices, the control of resale prices, limitations on access to information, and the like." Id. at p. 4 , col. 7. 
declaration that the contract or resolution is null and void, or for an injunction restraining the particular application of it." the public interest were to be held endangered "where production or supply" is restricted or prices raised or kept up ... to an extent which is econumically unjustifiable, or where economic freedom is restricted by means of buyers' or sellers' boycotts or inequitably affected by the fixing of differential prices and conditions of sale." 61 While the procedural details are different, ${ }^{02}$ this cartel statute has an uncomfortable resemblance to the proposal here under consideration. But perhaps we are no more than reasoning by analogy. "Cartel" is not-as Justice Frankfurter rightly points out-a talismanic word. ${ }^{63}$ Yet "cartel" does connote an absence or curtailment of competition, and competition is what the antitrust laws are designed to preserve. Unless we are to anticipate the "double-think" standards of 1984, we shall have to continue regarding price fixing as price fixing. ${ }^{\text {s }}$

\section{MoNOPOLY}

With regard to Section 2 violations, Professor Oppenheim observes that current debates over enforcing the law against monopoly bigness are merely symptomatic of "the underlying problem of discovering what is good bigness and what is bad bigness." structure standard under which oligopoly is often regarded as tacit group monopoly, and oligopoly conduct is considered equivalent to restrictive agreements among competitors, in the absence of proof of actual collusion. "In the process, the accomplishments of the oligopoly industry are given little or no weight at all."'66

For this reason both Professor Oppenheim and the Business Advisory Council suggest a new interpretation of Section 2 which would place primary

60. Liefarann, Cartels, Concerns and Trusts 351 (1932).

61. Id. at 352. To advocates of the "new" approach, this provision may prove disturbing because of the "per se" overtones and the Rutinsun-Patman type prohibitions implicit therein.

62. The main difference would appear to be in the allocation of the burden of proof. While the cartel statute places the entire burden on the government, Professor Oppanheim's "rule of reason" would require dcfondant to rebut a prims facie presumption with clear and convincing evidence of legal or economic justifications.

63. Timken Roller Bearing Co. v. United States, 341 U.S. 593, 605 (1951).

64. "Legal rules calling for price competition contain suund economic insight or intuition. MIore recent decisions which affirm and strengthen them may nut be dismisced summarily on economic grounds by vague references to newer notions of competition. If it had become necessary for courts to distinguish good cartels from lad cartels, or just prices from unjust prices, or to distinguish offsetting innovation advantages in determining the legality of price fixing arrangements, antitrust laws wuld probably have becume unenforceable or have been converted to instruments for increasing business regimentation." Bowman, Toward Less Monopoly, 101 U. of PA. L. REv. 577, 630 (1953).

65. Oppenheiss 1191.

66. Id. at 1190 (emphasis added). 
emphasis not on market structure but on market performance. ${ }^{07}$ Good monopolies would be distinguished from bad monopolies, hinging the difference between the two on the performance test of workable competition. Despite the statutory language which prohibits all monopolizing, ${ }^{08}$ Professor Oppenheim would condemn only those market organizations which are both monopolistic and injurious to the public interest. He apparently adopts the following criteria for judging performance in the public interest: "(1) Alternatives available to customers or sellers; (2) Volume of production or services; (3) Quality of the services or goods; (4) Number of people benefited; (5) Incentives to entrepreneurs; (6) Efficiency and economy in manufacturing or distribution; (7) The welfare of employees; (8) The tendency to progress in technical development; (9) Prices to customers; (10) Conditions favorable to the public interest in defending the country from aggression; (11) The tendency to conserve the country's natural resources; (12) Benefits to the public interest assuming the relief requested by the government in the proceedings." 69 This approach to the monopoly problem is subject to rather severe limitations.

\section{The Snare and Delusion of Workable Competition}

Workable competition overemphasizes the significance of inter-industry, inter-product, and technological competition. The Business Advisory Council, in illustrating the operation of workable competition, observes that altuminum "must compete with steel, copper, zinc, lead, tin, wood, textiles, plastics, paper, clay, glass, leather and cork. . . . Timber, the ancient material, has been rejuvenated through modern chemistry. The textile industry has been revolutionized both by chemistry and by technical machinery. The former transport dominance of the railroad industry has long been lost to highway and air competition. Such examples could be multiplied."70 To the

67. While Professor Oppenheim concedes the necessity of weighing "all of the relevant economic factors bearing upon the interaction of structure, behavior, and accomplishments in the particular case," OPPENHEn 1190, it is apparent that accomplishments (performance) occupy a central and dominant position in his trinity of standards.

The Business Advisory Council defines the rule of reason almost exclusively in terms of performance. Business Advisory Council 17.

68. See note 5 supra.

69. Smith, Effective Competition: Hypothesis for Modernising the Antitrust Laws, 26 N.Y.U.L.Q. Rev. 405 (1951), quoted in Oppenheim 1188. While Professor Oppenheim tentatively endorses these standards, he suggests that different standards may bo - equally acceptable if formulated by the national committee on the antitrust laws proposed in his article. Ibid.

These criteria are substantially the same as those recommended in Business Advisony Council 17. The only difference between the two versions is that the Business Advisory Council replaces the "welfare of employees" standard with "conditions favorable to the public interest in maintaining American investments abroad."

70. Business Advisory Council 14. 
Council this is proof of workable competition-or what it calls effective competition-in action. This it regards as preferable to the abstract and unrealistic "perfect" competition of classical economic theory as a standard for applied public policy. ${ }^{71}$

Three observations are relevant on this score. First, as Henry Simons has pointed out, "no sane advocate is asking for perfect competition, and no critic who is at once fair and competent will picture the [antitrust] policy as requiring drastic change in the organization of production. The requisite changes have to do mainly with ownership units and control devices not with operation."72 Antitrust supporters do not demand that the economy be purified right out of the twentieth century. ${ }^{73}$ They do suggest, however, that in most industries competition can be increased without diminution of technological efficiency.

Secondly, inter-industry competition as an economic force is more apparent than real. The fact is that when the paper container posed a threat to the tin can duopoly, Continental Can entered the paper container industry; when magnesium challenged the aluminum monopoly, Alcoa joined the magnesium cartel; when aluminum became a substitute for copper, Anaconda embarked on its venture into the aluminum industry. ${ }^{74}$ Today railroads control bus lines, shipping companies are tied to airlines, newspapers control radio stations, and TV outlets are operated by licensees of AMI stations. MIost serious, perhaps, is the Government's official blessing of important mergers in the communications industry, such as the recent combination of motion picture and television holdings. ${ }^{75}$ Besides being only a limited substitute for intra-industry rivalry, inter-industry competition can be manifestly subverted by control on the highest level of intercorporate finance.

71. Id. at 8 .

72. Simons, Econoxitc Policy for a Free Society 82 (1948).

73. See Kahn, Standards for Antitrust Policy, 67 Hans. L. REx. 28,35 (1953).

74. See Adams, Competition, Monopoly, and Counteriailing Poacor, 67 Q.J. Ecu::. 469 (1953).

75. In her dissenting opinion, FCC Commissioner Hennocls pointed out:

"In such a situation there is a substantial risk that the merged company, through the medium of ... restrictive practices, may subordinate its television interests to its motion picture exhibition interests, particularly so when the company's greater investments in theatres may be in an especially vulnerable or precarious position.

"Given the opportunity for economic gain through such restrictive practices, and in the absence of adequate safeguards against them, it cannot be assumed that the merged company will push its motion picture theatre and television interests fully and independently of each other, or to anywhere near the same extent that completely unfettered business competitors normally would."

American Broadcasting Co. and United Paramount Theatres, Inc., FCC Dlit. 1004t, 8 Pike \& Fischer, Radio Reg. Serv. 541, 631 (23) (1953) (dissenting opinion). 
Thirdly, inter-industry competition is perfectly compatible with a fully monopolized economy. Even if the aluminum, copper, steel, and magnesium industries were each a 100 percent monopoly, they could still theoretically compete with each other. Moreover, such competition might well qualify as "effective" under the standards of the Business Advisory Council, for there would still be "unhampered business incentives and freedom of choice, with reasonable alternatives for buyers and sellers."'70 The incentives, to be sure, would exist for the few and not the many; the alternatives would be those which the respective monopolists, in their role as industrial stewards, made available to the fortunate beneficiaries of modern technology.

\section{Workable Competition and Effective Antitrust Enforcement}

Workable competition tends to obliterate any practical guidelines to effective antitrust enforcement. It fails to indicate how much competition is required to satisfy its pragmatic demands. All we are told is that there must be enough competition to provide reasonable alternatives. "When consumers can choose freely between alternative sellers, each seller has an incentive to improve his product and lower his price. Consumers are thereby protected against monopolistic exploitation." 77

This is hardly a clear, definite, or measurable standard. ${ }^{78}$ Obviously, there will always be some competition and some freedom of choice under almost any form of economic organization. ${ }^{70}$ The history of cartels, for example, is replete with instances where cartel policy was undermined by ungentlemanly insiders or uncooperative outsiders. Even a tightly organized combination like the international oil cartel was continually plagued by periodic outbreaks of competition. ${ }^{80}$ The rubber cartel found that restrictive produc-

76. Business Advisory Council 8.

77. Id. at 9.

78. Dean Mason, probably the most sophisticated economist to advocate workable competition, concedes that a judicial evaluation of "performance" or "accomplishments" involves considerable difficulty. In testing adequate business performance, according to Mason, "it would have to be said that although it is 'probably possible to arrive at informed judgments, it is extremely difficult to devise tests that can be administered by a court of law.... No one familiar with the statistical and other material pertaining to the business performance of firms and industries would deny the extreme difficulty of constructing from this material a watertight case for or against the performance of particular firms in particular industries." Mason, The Current Status of the Monopoly Prob. lem in the United States, 62 HARv. L. Rev. 1265, 1281, 1282 (1949). There is considerable attraction in Mason's suggestion that performance be given some weight by the enforcement agencies in selecting cases for prosecution. Id. at 1284. Given their meager appropriations, these agencies have-of necessity-enormous discretion over the kinds of cases and the business areas in which to bring them.

79. Professor Chamberlin, a long time ago, pointed out that just as there is no "uerfect competition," so there is no "pure monopoly." Chamberlin, The Tugory of MoNOPOLISTIC COMPETITION (1st ed. 1933).

80. FTC, The International Petroleum Cartel (1952). 
tion quotas on the large plantations would be more than offset by the increased output of small, non-member producers. $\$ 1$ Similiarly, under the NRA, enforcement of code prices and quotas was more easily conceived in theory than achieved in practice. Despite the rather severe penalties for violation of the codes of "fair competition," there was a considerable number of "unethical chiselers" who rendered them unworkable. Finally, even in an industry which is completely monopolized there is still room for rather sharp intra-firm competition between the operating divisions of the monopoly.

The question remains therefore: how much competition must there be to qualify an industry as "workably competitive," or how much monopoly must be shown before antitrust action is justified? The workable competition advocates do not provide an answer. Nowhere do they cite a specific example of an American industry which is too monopolistic to be considered workably competitive. This is an ominous sign for the employment outlook in the market for antitrust lawyers.

\section{Workable Competition-a Cormucopia of Escape Hatches}

Before the courts could decree a violation of Section 2 under the standard of workable competition, there would have to be proof that defendants possessed monopoly power, and that defendants' course of conduct was inconsistent with such tests of market performance as conservation of resources, employee welfare, promotion of foreign investment, maintenance of entrepreneurial incentives, and conditions favorable to national defense. As if the specifically enumerated tests of "good" performance (public interest) did not offer enough loopholes, the Business Advisory Council reminds us that these tests are "relevant, but not exclusive." 82 We thus have the implicit assurance that should these performance standards fail to offer a sufficiently broad spectrum of defenses, others might be added to accommodate worthy defendants.

This almost preclusive reliance on market performance in judging the workability of competition raises at least two vexing problems. First, assuming that market performance in a particular industry is "good," the really significant question remains unanswered: have these favorable market results "been compelled by the system-by competition-or do they represent simply the dispensations of managements which, with a wide latitude of policy choices at their disposal, happened for the moment to be benevolent or 'smart' '?" 13 In other words, are there checks, balances, and incentives inherent in workable competition which offer reasonable assurance that the workable competition of today will not become the abusive monopoly or oppressive conspiracy of tomorrow? Secondly, what evidence is there that "those predatory or collusive actions which the law [now] attacks are indeed requisite to a

81. Stocking \& Watkins, op. cit. supra note 53, c. 3.

82. Business Advisory Council 17.

\$3. Lewis, Symposium on the Antitrust Lan's, 39 Axr. Ecos. Rew. 703, 707 (1949). 
good performance."84 Is there not a post hoc ergo propter hoc aspect to the contention that where performance of an industry is "good," this is due to conduct in violation of the antitrust laws? As Professor Kahn points out, the burden of proof in this respect rests with the advocates of workable competition. To date, they have not shouldered the risk of non-persunsion with any degree of success.

\section{Market Structure under Workable Competition}

The workable competition standard, in its preoccupation with market performance, tends to ignore some crucial implications of market structure. In fact, workable competition assumes in part that, if monopolistic abuses and predatory practices can be controlled, an industry's market structure is of secondary importance. Thus the advocates of workable competition would generally agree with Justice McKenna's dictum that "the law does not make mere size an offense or the existence of unexerted power an offense." 85 They would disagree with Professor Stigler's generalization that "an industry which does not have a competitive structure will not have competitive behavior."86

This aspect of workable competition-the "abuse" theory of size-is open to several major criticisms. In industries showing a structural deviation from the competitive norm, an attack on monopolistic practices can be likened to a treatment of the symptoms while ignoring the disease. The history of the United Shoe Machinery Corporation is a case in point. After an unsuccessful dissolution suit, ${ }^{87}$ the courts perpetually enjoined the company's use of the tying contract. ${ }^{88}$ It was hoped at the time that this prohibition would remove the primary means of lessening competition and creating monopoly. This turned out to be a vain hope, however, for the company substituted other provisions in its leasing contracts to achieve the same unlawful ends. ${ }^{80}$ Finding the highway to restraint of trade blocked, the monopolist simply traveled cross-country. As a result, 25 years after the injunction decree, the Antitrust Division felt compelled to attack the industry's monopolistic structure, in order to deal effectively with its monopolistic practices.

Moreover, the "abuse" theory of size ignores the economic realities of intercorporate relationships. ${ }^{90}$ Once a firm has attained a dominant position in

84. Kahn, supra note 73 , at 41 .

85. United States v. U. S. Steel Corp., 251 U.S. 417, 451 (1920).

86. The Case Against Big Business, Fortune, May, 1952, pp. 123, 167.

87. United States v. United Shoe Machinery Corp., 247 U.S. 32 (1918).

88. United Shoe Machinery Corp. v. United States, 258 U.S. 451 (1922) (under \& 3 of the Clayton Act).

89. United States v. United Shoe Machinery Corp., 110 F. Supp. 295 (D. Mass. 1953).

90. "Domination may spring as readily from subtle or unexercised power as from arbitrary imposition or command. To conclude otherwise is to ignore the realties of intercorporate relationships." North American Co. v. SEC, 327 U.S. 686, 693 (1946). 
the market place, it no longer has to engage in predatory practices to achieve its monopolistic ends. Its mere existence will be sufficient warning to smaller rivals that non-cooperation may be equivalent to suicide. ${ }^{\text {a1 }}$

Finally, it appears almost impossible to change oligopolistic market behavior without a transformation of oligopolistic market structure. This was dramatically indicated by defense counsel in the Tobacco case of 1946, , who observed that the Court's decision left the companies "entirely without guide as to how they may lawfully avoid the creation of evidence of future Sherman Act violations against themselves, unless they cease business altogether." 93 With justifiable consternation, counsel queried: "What are the specific policies and practices we must abandon, modify, or adopt in order to conduct our business according to law? ... Is everything the appellants do illegal, or evidence of illegality, if done by more than one of them?"'s: Neither the prosecution nor the courts provided an answer. ${ }^{93}$ The Tobacco case and similar prosecutions indicate the futility of condemning rational

91. "For the essense of restraint is power; and power may arise merely out of position. Whenever a dominant position has been attained, restraint necessarily arises." American Column \& Lumber Co. v. United States, 257 U.S. 377, 414 (1921) (dissenting opinion).

Thomas Nixon Carver rejected the "abuse" theory in non-legal, but picturesque, language:

"If I may use a homely illustration, I will take the common house cat, whose diminutive size makes her a safe inmate of our household in spite of her playiul disposition and her liking for animal food. If, without the slightest change of character or disposition, she were suddenly enlarged to the dimensions of a tiger, we should at least want her to be muzzled and to have her claws trimmed, whereas if she vere to assume the dimensions of a mastodon, I doubt if any of us would want to live in the same house with her. And it would be useless to argue that her nature had not changed, that she was just as amiable as ever, and no more carnivorous than she always had been. Nor would it convince us to be told that her productivity had greatly increased and that she could now catch more mice in a minute than she formerly could in a week. We should be afraid lest, in a playful mood, she might set a paw upon us, to the detriment of our epidermis, or that in her large-scale mouse-catching she might not always discriminate between us and the mice" Carver, Essays in Soctal Justice 332 (1915).

92. American Tobacco Co. v. United States, 323 U.S. 781 (1946).

93. Quoted in Nicholis, Price Policies in the Cigarette Iridustry 401 (1951).

94. Quoted id. at 402.

95. As a matter of pure logic it may, of course, be argued that there is more than one line of business conduct open to an oligopolist, and that the "collusive" behavior implicit in an oligopolistic market structure is by no means inevitable or inexorable. Dexter Keezer, Vice-President of the MIcGraw-Hill Book Company, for example, points out that as few as two firms may be enough theoretically to provide effective competition in an industry: "If the heads of the two surviving firms were the hard-driving, fiercely independent type of businessman who has played such a large part in the industrial development of the U.S.A., two of them would be enough to create a ruggedly competitive situation. But if the two were of the genteel, clubby and inclined-to-take-it-easy type which is also known in the high reaches of American business, two companies might get together and tend to sleep together indefinitely. When the number of firms involved is small, the clances of having the industry animated by vigorously competitive leadership also seems to me to 
oligopoly behavior without an attempt to change the market structure which makes the condemned behavior almost inevitable. ${ }^{00}$

\section{The Vulnerable Basic Premise of Workable Competition}

Workable competition rests on the unsubstantiated assumption that the present pattern of industrial concentration is an essential condition for efficiency and progress. According to the Business Advisory Council, "a big economy requires big industry. Without big enterprises, many constantly improved products cannot be turned out in the great quantities at the low prices that we Americans have come to expect-and demand."07 In a similar vein, Professor Oppenheim observes that "the real question is what form and degree of price competition can be realistically expected under specified conditions of imperfect competition." ${ }^{88}$ As if the necessity of giant size had been scientifically established, the search is launched for a compatible degree of monopoly power rather than for a market structure which can yield more competition within the limits of modern technology. ${ }^{00}$

To the writer's knowledge, no scientific study has yet demonstrated that giant size is imperative for the optimum utilization of modern technology or the attainment of efficiency in mass production industries. Indeed, some of the recent evidence has tended to point in the opposite direction. ${ }^{100}$ Fragmentary as it is, this evidence indicates, for example, that the giant U. S. Steel Corporation is no paragon of efficiency. A report prepared at the request of U.S. Steel itself pictured the corporation "as a big sprawling inert giant, whose production operations were improperly coordinated; suffering from a lack of

be relatively small." Keezer, Symposizun on the Antitrust Lazes, 39 AM. Econ. Rev. 703, 718 (1949).

For an incisive analysis of the behavioral consequences of an oligopolistic market structure, see Kaysen, Collusion under the Sherman Act, 65 Q.J. EcoN. 263 (1951).

96. Obviously, "no one can be forced to behave as if he possessed less intelligence than he really does. Specific manifestations of oligopolistic co-ordination can be suppressed. But in each case where this is done, it is necessary to ask the question as to what other manifestations of oligopolistic co-ordination are likely to show if certain business policies are outlawed. ... Unless the basic characteristics of the market structure itself are changed, the objectionable market results will be promptly replaced by different but equally oligopolistic results." Fellner, Collusion and its Limits under Oligopoly, 40 AM. EcoN. REv. SUPP. 55, 58-9 (1950).

97. Business Advisorx Counciz 3.

98. OPPEN HEIM 1191. (emphasis added).

99. The real problem is not "how much monopoly can safely be tolerated. The more important question is whether the entire community would be better off with more competition than now exists." Bowman, supra note 64, at 640-1. Bowman goes on to suggest that proof of monopoly should be rebuttable only by a showing that defendant had monopoly "thrust upon it," i.e., a showing that the economies of scale made monopoly inevitable. Bowman concludes that "considerable progress toward less monopoly (more competition) can be achieved in the public interest without departing from Judge Hand's 'thrust upon it' rule." Ibid.

100. Adams, The Dilemma of Antitrust Aims: A Reply, 42 Am. Econ. Rev. 895 (1952). 
a long-run planning agency; relying on an antiquated system of cost accounting; with an inadequate knowledge of the costs or of the relative profitability of the many thousands of items it sold; with production and cost standards generally below those considered everyday practice in other industries; with inadequate knowledge of its domestic markets and no clear appreciation of its opportunities in foreign markets; with less efficient production facilities than its rivals had; slow in introducing new processes and new products."101 On the basis of this powerful indictment, as well as other equally devastating evidence, some of our foremost economists concluded that the dissolution of U.S. Steel into at least three separate integrated units would not violate the demands of modern technology. They assured the Celler Committee: "One can be opposed to economic bigness and in favor of technological bigness in most basic industries without inconsistency. . . ."102

The experience under Section 11(b) of the Public Utility Holding Company Act of $1935^{103}$ is also noteworthy. It indicates that the comprehensive dissolution program under this Act did not preclude the optimum utilization of modern technology nor precipitate the fatal loss of efficiency which had been widely predicted prior to the law's passage. While the statistics are by no means conclusive, they do show that in most cases efficiency increased after dissolution, and that this increase was reflected in the security values of those operating companies which were divorced from their parent organizations. ${ }^{104}$ While investors profited, consumers simultaneously benefited from a decrease in utility rates which occurred despite rising operating costs and higher taxes. This was eloquent testimony to the wisdom and success of the dissolution program in the utility field. Here certainly was an industry requiring heavy capital investment, where a substantial amount of deconcentration did not produce the decline in operating efficiency which management spokesmen had expected and feared. While it is impossible to generalize on limited evidence of this sort, it would appear, nevertheless, that before any significant departures are authorized from traditional antitrust enforcement, the advocates of workable competition shall have to establish the inexorable link between giant size and industrial efficiency.

\section{Conclusion}

In conclusion, it may be well to remember that it is an antitrust law we are concerned with. The Sherman Act, as a charter of economic freedom, demands the promotion of more competition rather than the perpetual supervision of the policies and practices of monopoly. The Act is based on the

101. Testimony of Professor Stocking. Hearings before Subcommiltce on Sludy of Monopoly Power of the House Committe on the Judiciary, 81st Cong., 2d Sess. pt. IV-A 967 (1950). According to Professor Stocking, this was an unpublished report by the engineering firm of Ford, Bacon \& Davis.

102. Id. at 996 .

103. 49 Stat. $\$ 21$ (1935), 15 U.S.C. $\$ 79 k(b)$ (1946). See Comment, Scction 11(b) of the Holding Company Act: Fiftecn Years in Retrospect, 59 YALE L.J. $108 S$ (1950). 
theory that enforcement of competition "would contribute far more to the public interest in the level of costs and prices and in the economic allocation of capital than a programme of continuous surveillance of the business conduct of monopoly."105 In this sense, the Act is more than an instrument of trade regulation; it is an expression of a uniquely American political philosophy.

No one can deny that there are unresolved problems in applying the per se doctrine of Section 1 and the market structure test of Section 2. It cannot be argued, however, that the twin approach of workable competition and the rule of reason is well calculated to resolve these problems in a manner consistent with traditional antitrust objectives. The proposed approach fails to provide an adequate guide for public policy and, more importantly, may lead to the eventual marasmus of basic antitrust safeguards. In the final analysis, the proposed approach stands for a proposition long ago diagnosed by $\mathrm{Mr}$. Dooley: "The trusts are hideous monsters. On the one hand, I would stamp them under foot; on the other hand, not so fast."

104. Percentage Increase in Market Value of Common Stock of Certain Public Utility Holding Companies between Date of Registration under the Public Utility Holding Company Act of 1935 and September 24, 1951*

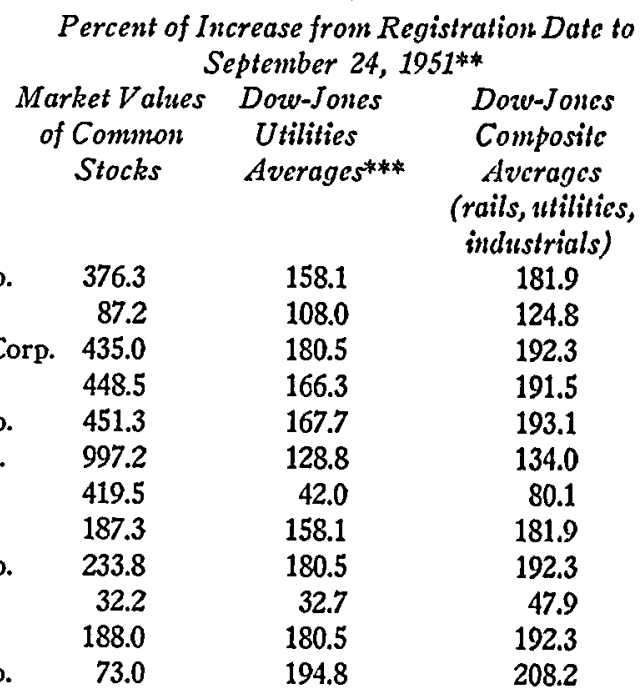

1. American Power \& Light Co. $\quad 376.3$

2. Columbia Gas System, Inc. $\quad 87.2$

3. Commonwealth \& Southern Corp. 435.0

4. Electric Bond \& Share Co. 448.5

5. Electric Power \& Light Corp. $\quad 451.3$

6. Engineers Public Service Co. $\quad 997.2$

7. Middle West Corp.

8. National Power \& Light Co.

9. Niagara Hudson Power Corp.

10. North American Co.

11. United Corp.

12. United Gas Improvement Co.

188.0

*Source: SEC, Report to the Senate Smalt Business Commitee: The Punlic Utilities Holding Conpany ACT of 1935 p. 21 (1952).

* The figures in these columns include the capital distributions of cash and portfolio or holding-company securities, taken at closing prices as of September 24, 1951, made to the holders of the common stocks of the holding companies listed herein.

***:The figures for percentage increase in the Dow-Jones averages (in this and the next column) are different for the different holding companies because the companies listed here registered under the Act on different dates. No inter-company comparisons should, therefore, be made.

105. Rostow, supra note 59 , at p. 6, col. 5 . 


\section{THE YALE LAW JOURNAL}

\section{EDITORIAL BOARD}

DAvid R. Hyde Editor-in-Chief

\author{
Richard A. SiEgal \\ Article and \\ Book Review Editor
}
MARVIN KATZ
David R. Tillinghist
JON R. WALTZ

Note and Comment Editors

WiLliam Baronoff

ROBERT WNY. BEREND

Richard K. Berg

Murry David Brochin

Barry R. Bryat

Thonzas N. Carruthers, Jr.

Jeromie A. Coher

LEWIS G. COLE

JoHA W. Colleran

WilliaAr H. Denspsey, Jr.

Russeil C. Dilks

DAvid A. Drexier

S. GORHON ELKINS

KLAUS Eprler

JOSEPH MI. FIEID
BerNaRd Finkelstei:

Joseph B. GildenhorN

Alan Gladstone

Howard Alan Glickstein

Noratan S. Goldsarttr

HaRold GRABINo

Anne Gross

Charles S. Haight, Jr.

ElLtot LeE HoffasaN

Alexander P. HoffaranN

ROBERT L. LASKY

NoEl ArNold LeviN

Cenarles S. Mfechey, Jr.

THoaras F. Nerson

\author{
PAyso: WOLFF \\ Manraging Edilor
}

\author{
Stuart 19. Palet \\ Alvin H. Scrulara: \\ JeANAE RITCHIE SILVER \\ Mo:moe Sillerusa: \\ Rrchano S. Siarso:is \\ Dasten M. Singers \\ Gorrox B. Spryck \\ Mfelvi: Ster: \\ David R. ToLr \\ STEPHE: W. Turl: \\ Gerald Walpi: \\ ROGER A. WeLCH \\ PAUL R. Weltchek \\ HAROLD AI. WIT \\ George C. Znchar:
}

\section{MaRIE MICDIAHON \\ Business Secretary}

\section{. CONTRIBUTORS TO THIS ISSUE}

Alfred E. KAHN, A.B. 1936, M1.A. 1937, New York University; Ph.D. 1942, Yale University. Associate Professor of Economics, Cornell University. MLember, AltorneyGeneral's National Committee to Study the Antitrust Laws.

Walter Adanus, A.B. 1942, Brooklyn College; M.A. 1946, Ph.D. 1947, Yale University. Associate Professor of Economics, Michigan State College. Miember, AttomeyGeneral's National Committee to Study the Antitrust Laws. 